\title{
Effect of plant growth-promoting rhizobacterial composite culture on the growth of chickpea seedlings
}

Jitendra Nag,

Biplab Dash,

Anup Kumar Singh,

Tapas Chowdhury,

Shyam Bihari Gupta,

\section{Ravindra Soni ${ }^{*}$}

Department of Agricultural Microbiology,

College of Agriculture,

IGKV, Raipur (C.G.)-492012, India
In the present study, 20 soil and plant samples from 13 villages of Raipur, Durg, and Balod District of Chhattisgarh (India) were collected from chickpea fields. From these samples, a total of 86 isolates including 16 Rhizobium, 40 Azotobacter, 29 Azosprillum, and one PSB were obtained on selective culture media. All the isolates were screened for their plant growth-promoting traits. Three (GmR8, ASL3 \& ASL4) out of 86 were finally selected for further studies. One Azotobacter isolate, i.e., Azo137, was selected from the departmental culture collection. Finally, four isolates including GmR8 (Rhizobium), ASL3, ASL4 (Azospirillum), and Azo137 were selected for composite culture formulations. GmR and ASL4 were siderophore-producing isolates, whereas ASL3 and Azo137 were IAA producer along with their ability to fix nitrogen. Five composite cultures were prepared randomly and tested for effect on the growth of chickpea (the seedling test and the pot experiment). Among all the composite culture groups, C2 (GmR8, Azo137, ASL4) significantly increased the root $(10.84 \mathrm{~cm})$ and shoot $(8.10 \mathrm{~cm})$ length, whereas biomass $(3.60 \mathrm{~g})$ was the highest in the case of $\mathrm{C} 1$ (GmR8, Azo137, ASL3, ASL4) of seedlings as compared to the control $(6.80 \mathrm{~cm}, 2.60 \mathrm{~cm}$, and $3.30 \mathrm{~g}$, respectively). Overall, the study revealed a better performance of composite or mixed culture over individual bacteria.

Keywords: rhizobacteria, consortia, chickpea, agriculture

\section{INTRODUCTION}

Chickpea is a very important pulse crop which contains $21.1 \%$ protein, $61.5 \%$ carbohydrates, and $4.5 \%$ fat. According to the FAO data, in 2016, world production of chickpeas was 12.1 million tonnes. (FAOSTAT, 2017). About 65\% of the global area with $68 \%$ of global chickpea production is contributed by India (Reddy and Mishra, 2010). The pro-

*Corresponding author. Email: rs31693@gmail.com duction is still not adequate to meet the domestic demand due to its low productivity $(850 \mathrm{~kg} / \mathrm{ha})$. The major causes of low productivity of chickpea in India are low yield potential and susceptibility of improved present-day cultivars to various biotic and abiotic stresses (Gowda et al., 2011).

A large array of bacteria including species of Arthrobacter, Alcaligenes, Azospirillum, Azotobacter, Bacillus, Burkholderia, Enterobacter, Klebsiella, Pseudomonas, and Serratia have been reported as plant growth-promoting rhizobacteria (PGPR) 
to enhance plant growth (Kloepper et al., 1988; Okon, Labandera-Gonzalez, 1994; Glick et al., 1995). Van Loon et al. (1997) critically reviewed the reasons for poor performance of agricultural bioinoculants in natural environments and in the plant rhizosphere after which he suggested that instead of using a single strain for a single trait, it was better to use a microbial consortium having multifarious uses. The present work is the initial step in the development of a microbial consortium for enhancing the growth of the chickpea.

\section{MATERIALS AND METHODS}

\section{Collection of soil samples and soil character- istics}

Twenty soil samples were collected from 13 villages in District Raipur, Durg, and Balod districts of Chhattishgarh (Table 1). Representative samples of surface soil with intact plants were collected from a chickpea growing farmer's field. These samples were properly tagged, sealed, and stored in a refrigerator for further study. Physicochemical properties like, determination of soil $\mathrm{pH}$, organic carbon, and dehydrogenase activity were determined by using previously described methods (Walkley, Black 1934; Klein et al., 1971).

\section{Isolation of plant growth-promoting rhizo- bacteria (PGPR)}

Isolation of plant growth-promoting bacteria was done by the serial dilution method followed by plating on Yeast Extract Mannitol Agar (YEMA) for (Rhizobium), Azospirillum agar, Azotobacter agar, and Pikovskaya's agar (for PSB), and incubated at their respective temperatures.

\section{Chrome azurol sulfonate assay for screning for siderophore production}

Chrome Azurol Sulfonate (CAS) dye measuring $60.5 \mathrm{mg}$ was dissolved in $50 \mathrm{ml}$ DI water

Table 1. Details of soil and plant samples collected from different locations in Chhattisgarh

\begin{tabular}{|c|c|c|c|c|c|}
\hline No. & Village name & Soil sample No. & $\mathrm{pH}$ & Organic carbon, \% & DHA (ugTPF/h/g) \\
\hline \multirow{2}{*}{1} & Achoti & 1 & 8.51 & 0.18 & 16 \\
\hline & & 2 & 7.09 & 0.345 & 24 \\
\hline \multirow{2}{*}{2} & Amethi & 1 & 6.99 & 0.67 & 26 \\
\hline & & 2 & 6.43 & 0.88 & 22 \\
\hline \multirow{2}{*}{3} & Malpuri khurd & 1 & 8.04 & 0.43 & 36 \\
\hline & & 2 & 7.81 & 0.315 & 20 \\
\hline \multirow{2}{*}{4} & Ahiwara & 1 & 7.17 & 0.165 & 14 \\
\hline & & 2 & 5.90 & 0.99 & 14 \\
\hline \multirow{2}{*}{5} & Sandi & 1 & 8.13 & 0.345 & 22 \\
\hline & & 2 & 8.18 & 0.78 & 37 \\
\hline \multirow{3}{*}{6} & Khamtarai & 1 & 7.92 & 0.58 & 41 \\
\hline & & 2 & 8.04 & 0.46 & 75 \\
\hline & & 3 & 8.28 & 0.84 & 30 \\
\hline 7 & Hingna & 1 & 8.09 & 0.33 & 40 \\
\hline 8 & $\begin{array}{c}\text { Meduka (Pendra } \\
\text { road ) }\end{array}$ & 1 & 5.47 & 0.43 & 44 \\
\hline 9 & Latabod (Balod) & 1 & 5.86 & 0.96 & 30 \\
\hline 10 & Sankara (Balod) & 1 & 5.94 & 1.215 & 108 \\
\hline 11 & Khuteri (Balod) & 1 & 7.68 & 0.705 & 18 \\
\hline 12 & Sankari(Balod) & 1 & 5.65 & 0.90 & 11 \\
\hline 13 & Limora (Balod) & 1 & 7.36 & 2.11 & 60 \\
\hline
\end{tabular}


and mixed with $10 \mathrm{ml}$ iron (III) solution (1 mM $\mathrm{FeCl}_{3} \cdot 6 \mathrm{H}_{2} \mathrm{O}$ and $\left.10 \mathrm{mM} \mathrm{HCl}\right)$. Under stirring the solution was added to $72.9 \mathrm{mg}$ HDTMA (Hexadecyltrimethylammonium bromide) dissolved in $40 \mathrm{ml}$ DI water. The resultant dark blue solution was autoclaved. A mixture of $750 \mathrm{ml}$ DI water, $100 \mathrm{ml} \mathrm{10X} \mathrm{MM9} \mathrm{salts}(60 \mathrm{~g} / \mathrm{L}$ $\mathrm{Na}_{2} \mathrm{HPO}_{4}, 30 \mathrm{~g} / \mathrm{L} \mathrm{KH}_{2} \mathrm{PO}_{4}, 5 \mathrm{~g} / \mathrm{L} \mathrm{NaCl}, 10 \mathrm{~g} / \mathrm{L}$ $\mathrm{NH}_{4} \mathrm{Cl}, 2 \mathrm{ml}$ of $1 \mathrm{M} \mathrm{MgSO}_{4}, 20 \mathrm{ml}$ of $20 \%$ glucose and $100 \mu \mathrm{l}$ of $1 \mathrm{M} \mathrm{CaCl}_{2}$ ), $15 \mathrm{~g}$ agar and $0.1 \mathrm{M} 10.29 \mathrm{~g}$ of Tris- $\mathrm{HCl}$ was made with $\mathrm{pH}$ of the solution 6.8 . After cooling to $50^{\circ} \mathrm{C}, 30 \mathrm{ml}$ of Tryptone as carbon source was added. Finally, the dye solution was added along the glass wall with enough agitation to achieve mixing without foaming (Schwyn, Neilands, 1987; Krey, 2008). Culture was directly spotted on CAS agar plates and incubated for $48 \mathrm{~h}$ at $28^{\circ} \mathrm{C}$ and examined for growth and production of orange halos surrounding the colonies (Krey, 2008).

\section{Formulation of composite cultures}

Four rhizobacteria isolates were finally selected based on their PGPR properties and compared alone and in combination with the chickpea seedlings germinated by paper towel method. Chickpea seeds were surface-sterilized with
$1 \%$ sodium hypochlorite for $5 \mathrm{~min}$ and washed five times with sterilized distilled water. Seeds were soaked with inoculum $\left(10^{8}-10^{9}\right.$ colony forming units (CFU)) for $5 \mathrm{~min}$, and dried in air. After bacterization, 50 seeds were placed in wet germination paper (three layers), covered with polythene, and incubated in incubator at $25^{\circ} \mathrm{C}$ for five days. Seeds soaked in distilled water were treated as control. Three replications for each treatment were maintained. The total number of treatments for this experiment was ten, which are summarized in Table 2.

\section{Seedling growth parameters}

The root length, shoot length, and fresh and dry weight were recorded for each seedling and the total nitrogen content in the seedlings was estimated by Micro-Kjeldahl method as described by Jackson (1973) using auto digestion and distillation system. Available nitrogen was determined by alkaline $\mathrm{KMnO}_{4}$ method of Subbiah and Asija (1956).

\section{RESULTS AND DISCUSSION}

Out of 20 plant samples, only 16 had good nodules. From these 16 samples, Rhizobium was

Table 2. Details of seedling treatment along with PGP properties of different PGPRs used in this study

\begin{tabular}{|c|c|c|c|}
\hline Treatment & Details & PGPR & PGPR properties \\
\hline $\mathrm{T} 1$ & $\mathrm{C} 1$ & GmR8+AZO137+ASL3+ASL4 & $\begin{array}{l}\text { BNF, siderophore production, IAA, } \\
\text { temperature, } \mathrm{pH} \text {, salt tolerance }\end{array}$ \\
\hline $\mathrm{T} 2$ & $\mathrm{C} 2$ & GmR8+AZO137+ASL4 & $\begin{array}{l}\text { BNF, siderophore production, IAA, } \\
\text { temperature, } \mathrm{pH} \text {, salt tolerance, }\end{array}$ \\
\hline T3 & C3 & GmR8+ASL3 & BNF, siderophore production, IAA \\
\hline $\mathrm{T} 4$ & $\mathrm{C} 4$ & AZO137+ASL3+ASL4 & $\begin{array}{c}\text { IAA, temperature, } \mathrm{pH} \text {, salt tolerance, } \\
\text { BNF, siderophore production }\end{array}$ \\
\hline T5 & $\mathrm{C} 5$ & AZO137+ASL3 & $\begin{array}{l}\text { IAA, temperature, } \mathrm{pH} \text {, salt tolerance, } \\
\text { BNF, siderophore production }\end{array}$ \\
\hline T6 & GmR8 & Rhizobium isolate (from this study) & BNF, siderophore production \\
\hline T7 & Azo137 & $\begin{array}{c}\text { Azotobacter } \\
\text { (selected from previous study Nag 2015) }\end{array}$ & $\begin{array}{c}\text { BNF, IAA, temperature, } \mathrm{pH} \text {, salt } \\
\text { tolerance }\end{array}$ \\
\hline $\mathrm{T} 8$ & ASL3 & $\begin{array}{l}\text { Azosprillum } \\
\text { (from this study) }\end{array}$ & BNF, IAA \\
\hline T9 & ASL4 & Azosprillum(from this study) & BNF, siderophore production \\
\hline $\mathrm{T} 10$ & Control & & \\
\hline
\end{tabular}


successfully isolated on YEMA plates. These isolates were then further screened for their ability of producing siderophores and IAA. Out of 16 samples screened, only one isolate (GmR8) was found to possess the ability of producing siderophores on a CAS agar plate. A total of 86 isolates were then tested for their ability to produce IAA and siderophore. Out of 86 isolates, one Rhizobium isolate (GmR8) and one Azospirillum (ASL4) were siderophore-producing whereas ASL3 (Azospirillum) was IAA-producing (Fig. 1).

\section{Formulation of the composite culture}

Four bacterial isolates were finally selected for further study, based on their plant growth-promoting ability. One out of four, Azo137, was selected from a previous study conducted in the department of Agricultural Microbiology, College of Agriculture, Raipur (Nag, 2015). Five different compositions were formulated randomly by using these four isolates (Table 2).

\section{Effect of composite cultures on chickpea seedlings}

The observations of seedling treatment were recorded after five days of germination. Growth parameters in incubated conditions showed significant difference as compared to that of the control (Fig. 2). The data presented in Table 3 indicated that the increase in the shoot length of the seedlings was in the range of 2.60 to $8.10 \mathrm{~cm}$.
The shoot length of the seedlings observed were $7.65,8.10,4.14,6.76,6.71,6.35,4.72,4.41,3.26$, and $2.60 \mathrm{~cm}$ from $\mathrm{T} 1, \mathrm{~T} 2, \mathrm{~T} 3, \mathrm{~T} 4, \mathrm{~T} 4, \mathrm{~T} 5, \mathrm{~T} 6$, T7, T8, T9 and T10, respectively. Also, this study revealed that the biggest shoot length was found to be $8.10 \mathrm{~cm}$, followed by $7.65 \mathrm{~cm}$ on $\mathrm{T} 2$ and T1, respectively, which was significantly bigger than the control, i.e., $2.60 \mathrm{~cm}$ (T10). Similarly, the variation in the root length was found to be between 6.80 and $10.84 \mathrm{~cm}$ out of which the biggest was recorded in T2. There was a significant increase in fresh weight of seedling from 9.23 to $13.93 \mathrm{~g}$. The highest being $13.93 \mathrm{mg}$ was followed by $13.53 \mathrm{mg}$ from treatment T1 and T3, respectively among all the treatments. Further, the highest dry weight of seedling per seedling was found to be $3.93 \mathrm{~g}$ which is an increase of about $0.60 \mathrm{~g}$ from the lowest, that of the control.

There is a clear indication from the experimental data that there was a noteworthy jump in nitrogen content (seedling nitrogen content) from $11.32 \%$ in the control to $17.66 \%$ in $\mathrm{T} 1$ due to seed inoculation. The lowest value among the inoculated treatments remains at $15.66 \%$ in T8. The overall result revealed that the composite culture C1, i.e., (GmR8+Azo137+ASL3+ASL4) remarkably increased the root and shoot length along with biomass of seedlings as compared to that of the control. There was no significant variation observed in the pot experiment except nodulation among all the parameters studied.

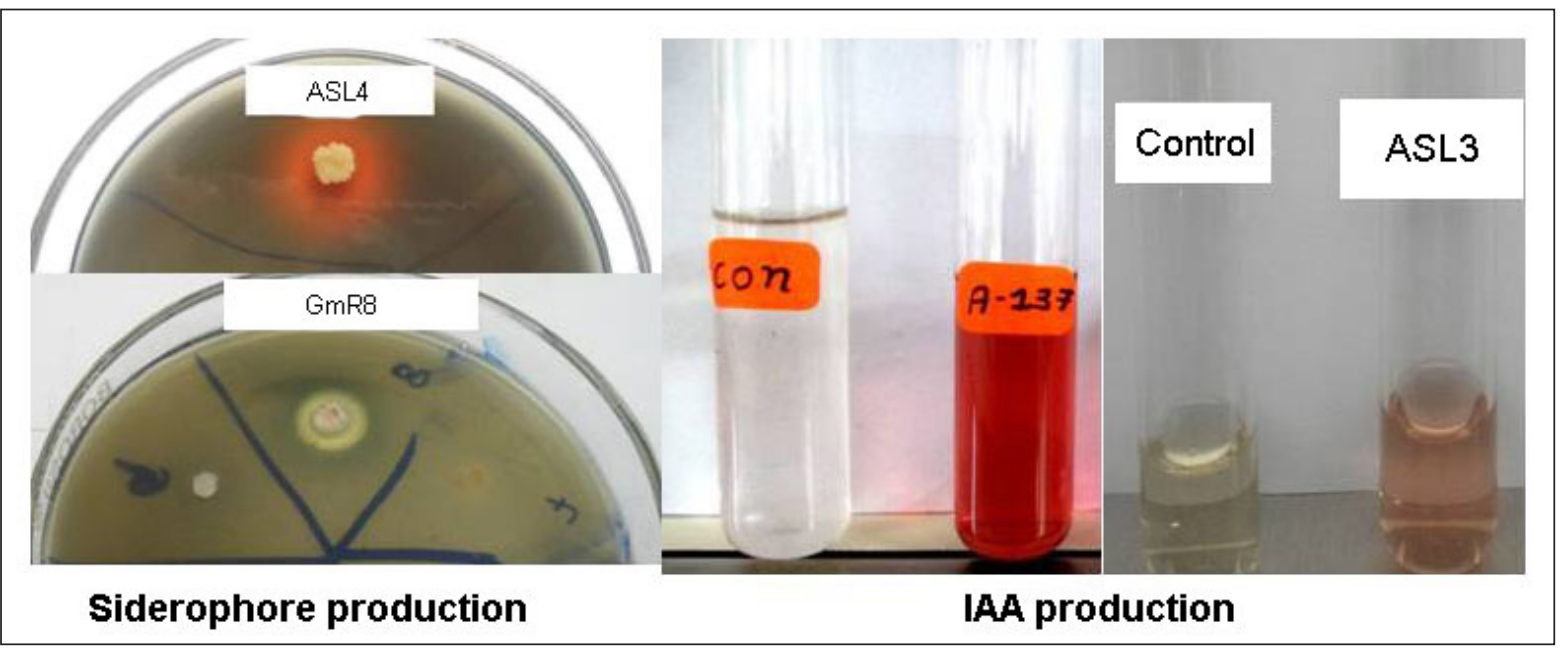

Fig. 1. Bacterial isolates selected for the study 


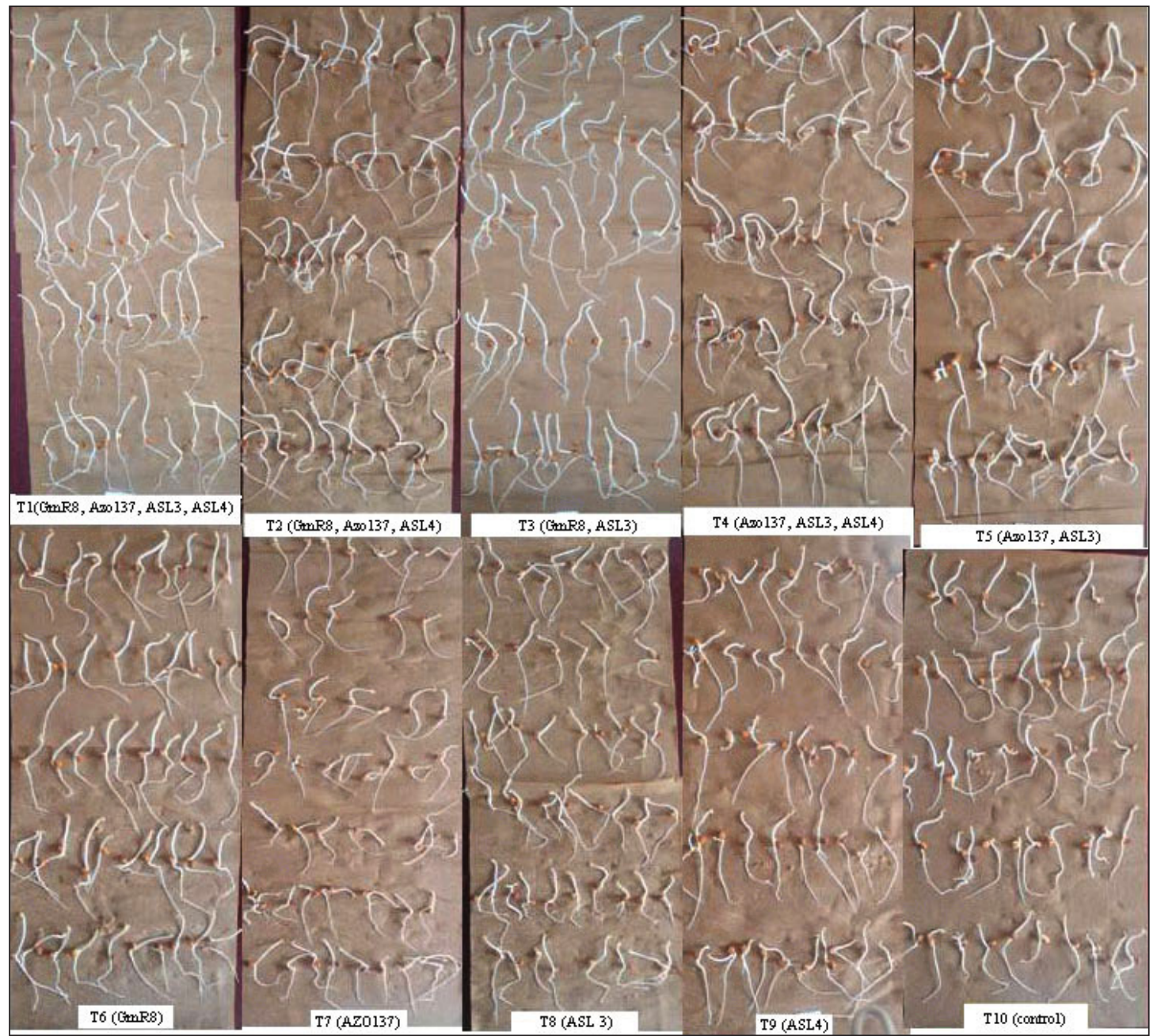

Fig. 2. Effect of composite culture on chickpea seedlings

Table 3. Effect of the multipurpose composite culture on the growth of chickpea seedlings. The chickpea seedlings were germinated for five days and the following different parameters were observed

\begin{tabular}{c|c|c|c|c|c|c}
\hline $\begin{array}{c}\text { Treat- } \\
\text { ments }\end{array}$ & & $\begin{array}{c}\text { Seedling nitro- } \\
\text { gen content, } \%\end{array}$ & $\begin{array}{c}\text { Fresh weight } \\
\text { of seedling, }\end{array}$ & $\begin{array}{c}\text { Dry weight } \\
\text { of seedling, }\end{array}$ & $\begin{array}{c}\text { Shoot length of } \\
\text { seedling, } \mathbf{c m}\end{array}$ & $\begin{array}{c}\text { Root length of } \\
\text { seedling, } \mathbf{c m}\end{array}$ \\
\hline T1 & C1 & 17.66 & 13.93 & 3.93 & 7.65 & 9.93 \\
\hline T2 & C2 & 15.99 & 11.50 & 3.60 & 8.10 & 10.84 \\
\hline T3 & C3 & 16.99 & 13.53 & 3.80 & 4.14 & 7.40 \\
\hline T4 & C4 & 16.66 & 13.10 & 3.63 & 6.76 & 9.25 \\
\hline T5 & C5 & 15.99 & 12.60 & 3.53 & 6.71 & 9.35 \\
\hline T6 & GmR8 & 16.09 & 11.57 & 3.57 & 6.35 & 7.63 \\
\hline T7 & AZO137 & 17.59 & 10.83 & 3.40 & 4.72 & 7.84 \\
\hline T8 & ASL3 & 15.66 & 12.50 & 3.43 & 4.41 & 7.66 \\
\hline T9 & ASL4 & 16.36 & 9.90 & 3.63 & 3.26 & 7.45 \\
\hline T10 & Control & 11.32 & 9.23 & 3.30 & 2.60 & 6.80 \\
\hline S Em & & 0.515 & 0.515 & 0.186 & 0.3090 & 0.4240 \\
\hline CD & & 1.543 & N/A & 0.9260 & 1.2690 \\
\hline
\end{tabular}


However, nodulation in the treatment associated with $\mathrm{C} 1$ composite group was also found to be good.

PGPR are the invisible entity behind the visible physical growth of plants. A wide range of applicability starting from enhancing the nutrient uptake and production growth regulators in plants to siderophore production and serving as a biocontrol agent are the few beneficial effects of PGPR worth mentioning (Vejan et al., 2016). Considerable amount of studies have been conducted on the effect of plant growth-promoting rhizobacteria on the growth of chickpeas by a number of researchers (Karnwal, Kumar, 2012; Yadav et al., 2010; Dasgupta et al., 2015). However, very little progresses on the application of composite culture of PGPR on chickpea growth has been highlighted. One such work on composite culture was carried out by Wani et al. (2007) by inoculating Mesorhizobium ciceri with Azotobacter chroococcum and Bacillus sp. and, indeed, the results were very encouraging. A threefold increase in the seed yield was observed, followed by an increase in the seed protein level. Also an enhancement in pod and straw yield was noted by Qureshi et al. (2009) by co-inoculating Mesorhizobium ciceri and Bacilus megaterium in chickpea. Similar results of the use of composite cultures of PGPR on plant growth were also seen in several other crops like maize (Agbodjato et al., 2016), wheat (Khan, Zaidi, 2007), common bean (Korir et al., 2017), and green gram (Gupta et al., 2003).

Several scientific researchers are in tune with the view that a composition of many PGPRs always gives a better result as compared to individuals (Martins et al., 2004; Ladwal et al., 2012; Chandra, Pareek, 2015) and this case there was no exception. Growth parameters like nitrogen content, fresh and dry weight, shoot length as well as root length were much higher in $\mathrm{C} 1$ than in T6, T7, T8, and T9, which were composed of single inoculants. However, it must also be kept in mind that compatibility among different microbial genera and strains must be a positive and synergistic one (Tilak et al., 2006). As per the data obtained from the above experiment, $\mathrm{C} 1$ culture stands ahead of other composite cul- tures, i.e., $\mathrm{C} 2, \mathrm{C} 3, \mathrm{C} 4$, and $\mathrm{C} 5$ with respect to most of the growth parameters studied. Thus, this highly signifies the importance of suitable compatibility among different microbial strains that is to be strictly maintained. Finally, after analyzing the experimental data, we could arrive at a conclusion that the use of a composite culture of PGPR in chickpeas could pave the way for a multifaceted effect on plant growth.

\section{ACKNOWLEDGEMENTS}

The present study was financially supported by a grant of the Chhattisgarh Council of Science and Technology, Raipur (Chhattisgarh) to Ravindra Soni.

Received 3 February 2017

Accepted 4 September 2017

\section{References}

1. Agbodjato NA, Noumavo PA, Adjanohoun A, Agbessi A, Moussa LB. Synergistic effects of plant growth promoting rhizobacteria and chitosan on in vitro seeds germination, greenhouse growth, and nutrient uptake of maize (Zea mays L.). Biotechnolo Res Int. 2016; 7830182.

2. Chandra R, Pareek N. Comparative performance of plant growth promoting rhizobacteria with rhizobia on symbiosis and yields in urdbean and chickpea. J Food Legumes. 2015; 28(1): 86-9.

3. Dasgupta D, Ghati A, Sarkar A, Sengupta C, Paul G. Application of plant growth promoting rhizobacteria (PGPR) isolated from the rhizosphere of Sesbania bispinosa on the growth of chickpea (Cicer arietinum L.). Int J Curr Microbiol App Sci. 2015; 4(5): 1033-42.

4. Glick BR, Karaturović DM, Newell PC. A novel procedure for rapid isolation of plant growth promoting Pseudomonads. Can J Microbiol. 1995; 41: 533-6.

5. Gowda CLL, Upadhyaya HD, Dronavalli N, Singh S. Identification of large-seeded highyielding stable kabuli chickpea germplasm lines 
for use in crop improvement. Crop Sci. 2011; 51: 198-209.

6. Gupta A, Saxena AK, Gopal M, Tilak KVBR. Effects of co-inoculation of plant growth promoting rhizobacteria and Bradyrhizobium sp. (Vigna) on growth and yield of green gram (Vigna radiata (L.) Wilczek. Trop Agric. 2003; 80(1): 28-35.

7. Jackson ML. Soil chemical analysis. New Delhi: Prentice Hall of India Pvt. Ltd.; 1973. p. 498.

8. Karnwal A, Kumar V. Influence of plant growth promoting rhizobacteria (PGPR) on the growth of chickpea (Cicer arietinum L.) Annals. Food Sci and Tech. 2012; 13(1): 43-8.

9. Khan MS, Zaidi A. Synergistic effects of the inoculation with plant growth promoting rhizobacteria and an arbuscular mycorrhizal fungus on the performance of wheat. Turk J Agric. 2007; 31: 355-62.

10. Klein DA, Loh TC, Goulding RL. A rapid procedure to evaluate the dehydrogenase activity of soils low in organic matter. Soil Bid Biochem. 1971; 3: 385-7.

11. Kloepper JW, Hume DJ, Scher FM, Singleton C, Tipping B, Laliberté M, Frauley K, Kutchaw T, Simonson C, Lifshitz R, Zaleska I, Lee L. Plant growth-promoting rhizobacteria on canola (rapeseed). Plant Disease. 1988; 72: 42-5.

12. Korir H, Mungai NW, Thuita M, Hamba Y, Masso C. Co-inoculation effect of rhizobia and plant growth promoting rhizobacteria on common bean growth in a low phosphorus soil. Front Plant Sci. 2017; 8: 141.

13. Krey WB. Siderophore production by heterotrophic bacterial isolates from the Costa Rica upwelling dome [dissertation]. 2008.

14. Ladwal A, Bhatia D, Malik DK. Effect of coinoculation of Mesorhizobium cicer with PGPR on Cicer arietinum. Aust J Basic Appl Sci. 2012; 6(9): 183-7.

15. Martins A, Kimura O, Goi SR, Baldani JI. Effect of the co-inoculation of plant growth-promoting rhizobacteria and rhizobia on development of common bean plants (Phaseolus vulgaris L.). Flore Am. 2004; 11(2): 33-9.
16. Nag NK. Selection of stress tolerant effective Azotobacter isolates for climatic conditions of Chhattisgarh [M.Sc. Ag. dissertation]. Indira Gandhi Krish Vishwavidyalaya. Raipur, India; 2015.

17. Okon Y, Labandera-Gonzalez CA. Agronomic applications of Azospirillum: an evaluation of 20 years worldwide field inoculation. Soil Biol Biochem. 1994; 26: 1591-601.

18. Reddy A, Mishra D. Growth and instability in chickpea production in India: a state level analysis. 2010.

19. Qureshi MA, Shakir MA, Naveed M, Ahmad MJ. Growth and yield response of chickpea to co-inoculation with Mesorhizobium ciceri and Bacillus megaterium. J Animal and Plant Sci. 2009; 19(4): 205-11.

20. Schwyn B, Neilands JB. Universal chemical assay for the detection and determination of siderophores. Anal Biochem. 1987; 160(1): 47-56.

21. Subbaiah BV, Asija GL. A rapid procedure for the estimation of available nitrogen in soil. Curr Sci. 1956; 25: 259.

22. Tilak KVBR, Ranganayaki C, Manoharachan C. Synergistic effects of plant growth promoting rhizobacteria and Rhizobium on nodulation and nitrogen fixation by Pigeon pea (Cajanus cajan). Eur J SoilSci. 2006; 57: 67-71.

23. Van Loon LC. Induced resistance in plants and the role of pathogenesis-related proteins. Eur J Plant Pathol. 1997; 103: 753-65.

24. Vejan P, Abdullah R, Khadiran T, Ismail S, Boyce AN. Role of plant growth promoting rhizobacteria in agricultural sustainability. Molecules. 2016; 21(573).

25. Walkley A, Black IA. An examination of Degtjareff method for determining soil organic matter and a proposed modification of the chromic acid titration method. Soil Sci 1934; 37: 29-37.

26. Wani PA, Khna MS, Zaidi A. Synergistic effects of the inoculation with nitrogen-fixing and phosphate-solubilizing rhizobacteria on the performance of field-grown chickpea. J lant Nutr Soil Sci. 2007; 170: 283-7. 
27. Yadav J, Verma JP, Tiwari KN. Effect of plant growth promoting rhizobacteria on seed germination and plant growth chickpea (Cicer arietinum L.) under in-vitro conditions. Biological Forum Int J. 2010; 2(2): 15-8.

Jitendra Nag, Biplab Dash, Anup Kumar Singh, Tapas Chowdhury, Shyam Bihari Gupta, Ravindra Soni

\section{RIZOBIJŲ KULTŪRŲ POVEIKIS SĖJAMOJO AVINŽIRNIO DAIGŲ AUGIMUI}

Santrauka

Šio tyrimo metu iš 13 kaimų (Raipur, Durg ir Balod rajonai, Indija) buvo surinkti sejjamojo avinžirnio laukų dirvožemio ir augalų mèginiai. Iš visų selektyvios kultūros terpès mėginių atrinkti 86 izoliatai, iš kurių 16 buvo Rhizobium, 40 Azotobacter, 29 Azosprillum ir vienas PSB. Patikrinta, kokias augimo savybes skatino visi izoliatai. Trys (GmR8, ASL3 ir ASL4) iš 86 izoliatų buvo atrinkti tolesniam tyrimui. Vienas Azotobacter izoliatas (Azo137) buvo parinktas iš Žemès ūkio mikrobiologijos departamento kultūrų kolekcijos. GmR8 ir ASL4 izoliatai gamino sideroforą, o ASL3 ir Azo137 buvo IAA gamintojai ir gebejjo fiksuoti azotą. Iš visų sudètinių kultūrų grupių C2 (GmR8, Azo137, ASL4) gerokai padidino šaknies $(10,84 \mathrm{~cm})$ ir ūglio $(8,10 \mathrm{~cm})$ ilgị, didesne biomase $(3,60 \mathrm{~g})$ pasižymèjo $\mathrm{C} 1 \mathrm{GmR} 8$, Azo137, ASL3, ASL4) sèklos, palyginti su kontroline grupe (atitinkamai $6,80 \mathrm{~cm}, 2,60 \mathrm{~cm}$ ir 3,30 g).

Raktažodžiai: rizobijos, konsorciumas, sẻjamasis avinžirnis, žemdirbystẻ 